\title{
Inequality Within the EU-15 Countries: Have Social Benefits Been Pro-poor, Pro-middle Class or Pro-rich?
}

\author{
Abdulaleem Isiaka \\ Department of Economics, University of Reading \\ Whiteknights, PO Box 218 Reading, RG6 6AA, United Kingdom \\ Tel: +447448587494Ｅ-mail: a.m.isiaka@pgr.reading.ac.uk
}

Received: February 27, 2020 Accepted: March 29, 2020 Published: April 13, 2020

doi:10.5296/ijssr.v8i2.16571ＵRL: http://dx.doi.org/10.5296/ijssr.v8i2.16571

\begin{abstract}
This study utilizes static and dynamic panel models in investigating the impact of social benefits on the aggregate level of income inequality as well as on the income shares of different income groups within the EU-15 countries over the period 1995-2015. While the static panel regression models are estimated with Pooled Ordinary Least Squares (POLS) and Least Squares Dummy Variables (LSDV) techniques, the dynamic panel regressions are estimated using dynamic GMM-IV technique. Diagnostic tests indicate that the results from the GMM-IV technique are consistent and the associated instrumental variables are valid; hence this study gives preference to the results from this technique. The results indicate that social benefits generally have a significantly negative impact on the aggregate level of inequality, a positive impact on the income shares of the low and middle income groups, and a negative impact on the income shares of the high income groups. In the long run, the sign and significance of the parameter estimates remain unchanged but their sizes increase considerably. This research considers a variety of theories and finds that there exists much ambiguity in the theoretical literature. Based on its findings, this study recommends that policymakers address rising income inequality by intensifying efforts towards raising social benefits and ensuring that the welfare system is efficiently managed.
\end{abstract}

Keywords: EU-15 countries; Income inequality; Social benefits, Panel data, Income shares. 


\section{Introduction}

Although rising income inequality in Europe has been blamed on the adoption of policies that are pro-liberalization, pro-welfare state retrenchment and pro-financialization, these policies have also had desirable impacts on economic growth and poverty (Chen, 2010; OECD, 2011; Milanovic, 2012). This paradoxical outcome illustrates the policy relevance of inequality since policymakers aim at rebalancing the economy by promoting sustainable growth without increasing inequality.

Likewise, the relevance of inequality from an empirical perspective is indicated by the concerning trends of inequality since the 1980s. The World Bank (2018a) observes that the European Union (EU) in the mid-1980s was characterized by a considerably wide gap between the rich and the poor. As incomes climbed in the late 1980s and early 1990s, inequality soared. By 2014, the income distributions of EU-17 South countries and Central and Eastern Europe (CEE) had become more unequal than the OECD average. Likewise, IMF (2012) asserts that a sizable number of developed and developing European countries witnessed a 3 percentage point rise in inequality between 1990 and 2005. The increase was most pronounced in developing European countries. Similarly, OECD (2017) notes that between 1980 and 2014, the Gini coefficient climbed from 0.28 to 0.30 in Europe. Surprisingly, this period witnessed an increase in inequality in traditionally equal countries such as Finland and Sweden. Further, findings of the Eurofound (2010) suggest that the total income of a large chunk of workers has reduced over the years and the income distribution of Europe is more unequal than what obtained in the 1980s. Also, the 2007-2009 crisis heightened concerns regarding inequality owing to the potential consequences of the decline in the fiscal stimulus policies of many European countries. The post crisis years were characterized by a reduction in social benefits.

Meanwhile, there is a debate in the theoretical literature regarding the relative importance of social benefits in reducing inequality. The median voter model of Meltzer and Richard (1981) predicts that an increase in social benefits would likely increase inequality due to the median voters' pursuit of their personal interests. However, the political economy-growth model of Alesina and Perotti (1994) suggests that an increase in social benefits would achieve the objective of reducing inequality as redistributive policies would reduce the incomes of the high income groups in a manner that benefits other income groups without contributing to inequality. Also, Bénabou's (2000) stochastic growth model suggests that inequality increases at low levels of social benefits and decreases as social benefits become considerably high. Further, the hypotheses based on the mainstream labour supply theory (Aaberge \& Colombino, 2006) suggest that benefits could serve as an incentive for recipients to reduce working hours, thereby increasing wage inequality. This apparent ambiguity indicates the importance of inequality form a theoretical and academic perspective.

Likewise, the empirical literature is not at a consensus regarding the impact of social benefits on inequality. While some empirical findings suggest a negative impact, some suggest a positive impact and others arrive at less straight forward conclusions (see, for example, Dafermos \& Papatheodorou, 2012; Butler \& Kondratas, 1987; Lee, 1987; Murray, 1984; 
Heady et al., 2001; Niehues, 2010).

However, the existing literature gives little or no consideration to the impact of social benefits on the income shares of different income groups. The need to consider the income groups arises from the fact that the Gini coefficient only provides information about the income gap between the rich and the poor; it does not provide adequate information about the gap between subtly defined income groups such as the working class and the middle income class (Hayes \& Vidal, 2015). Similarly, the study of the income groups makes it possible to ascertain whether social benefits have been pro-poor, pro-middle class or pro-rich. Additionally, most studies adopt a single estimation technique and fail to robustly address issues related to endogeneity, heterogeneity and inequality persistence. Further, many studies omit some key determinants of inequality.

Against this backdrop, the general aim and objective of this study is to investigate the impact of social benefits on inequality as well as on percentile income shares in the EU-15 countries over the period 1995-2015. This research hypothesizes that social benefits have a significant impact on inequality as well as the percentile income shares. The contributions of this study firstly entail; evaluating the impact of social benefits on inequality at an aggregate level as well as on the income shares of different income groups; viz. the low, middle and high income groups. While aggregate inequality is measured using the Gini coefficient, the income groups are measured using the income shares of six different income percentiles; data are from Eurostat's Database. Secondly, three estimation techniques are adopted in accounting for inequality persistence, endogeneity, and heterogeneity. Specifically, this research adopts the Pooled Ordinary Least Squares (POLS) which includes control variables that account for potential endogeneity arising from the omission of observed heterogeneity. Also, this study adopts Least Squares Dummy Variables (LSDV) which includes country and time fixed effect that control for potential endogeneity arising from the omission of unobserved heterogeneity. Thereafter, this study adopts GMM-IV estimator of Arellano and Bond (1991) which controls for inequality persistence and potential endogeneity arising from reverse causality. The variety of results and perspectives obtained from employing multiple methods makes this research more robust, comprehensive and rigorous. Thirdly, this research considers key determinants of inequality which have been ignored in many studies; such as finance and trade union density.

The rest of this study proceeds as follows: Section 2 reviews the literature. Section 3 sets out the main methods, identifies the hypotheses and describes the data. Section 4 presents the results and the main analysis. Section 5 summarizes and concludes.

\section{Literature Review}

\subsection{Theoretical Literature}

Although a variety of theories have been introduced regarding the relationship between social benefits and inequality, this study considers those theories that are most relevant.

The median voter model of Meltzer and Richard (1981) suggests that a rise in social benefits results in an increase in inequality. The model is built on the fundamental assumption that 
income is unequally distributed. Additionally, it rests on the supposition that; although the median income is considerably less than the mean income, the interests of those possessing the median income (median voters) largely determine the taxing and redistribution decisions in a majority voting system. Further, the model argues that the median voters pursue their personal interests by influencing continuous increases in progressive taxes so as to raise social benefits to a level that allows them optimize earnings despite reducing their working hours. Consequently, social benefits would not only be ineffective in reducing inequality but would in fact aggravate inequality.

Likewise, the political economy-growth model of Alesina and Perotti (1994) suggests that social benefits are indeed effective in reducing inequality. Further, this model relies on the assumption that; as inequality increases, more public funds accumulate to the individuals possessing high incomes thereby allowing them exert some influence on the taxing and spending policies. Accordingly, this decreases the strength of the median voters and ultimately ensures that social benefits are not so large that they encourage reduction in labour supply (Rodriguez, 1999).

Bénabou's (2000) stochastic growth model also sheds some light on the relationship between social benefits and inequality. The model is based on the assumption that redistribution policies have some failings. Further, the model suggests that the impact of social benefits on inequality depends on how large the benefits are as well as the degree to which the capital market is imperfect. A high degree of imperfection in capital markets results in differences in the investment opportunities of the rich and the poor; and this coupled with low social benefits raises inequality. However, inequality may fall as social benefits become considerably high.

Further, mainstream labour supply theory indicates that benefits may serve as a disincentive for recipients to supply labour since they would be able to earn a given amount of income by working for fewer hours. If the reduction in working hours is higher among low income workers relative to high income workers, inequality would increase (Aaberge \& Colombino, 2006).

\subsection{Empirical Literature}

Despite the increasingly growing debates regarding the role of social benefits in reducing inequality in Europe, the inequality-growth nexus debate still receives comparatively greater attention in the literature. Expectedly, studies on the inequality-growth nexus do not set out to contribute to the debate on the impact of social benefits on inequality (see, for example, Alesina \& Rodrik 1994; Perotti 1996; Barro 2000; Easterly 2000; Ostry et al., 2014; Cingano 2014; Madsen et al., 2018). Hence, there is a very limited extent to which such studies can be relevant to the debate.

This study surveys the empirical literature based on the outcomes of studies. While some studies find that social benefits have a negative impact on inequality, some find a positive impact and others reach less straightforward conclusions. 


\subsubsection{Studies That Find a Negative Impact of Social Benefits on Inequality}

While some of these studies adopt descriptive approaches, others adopt econometric approaches. The descriptive study of Leschke and Jepsen (2012) argue in favour of an increase in social benefits as austerity measures could aggravate inequality within and across many EU countries. These arguments also corroborate those of Ivanova (2007) in a descriptive study on selected European countries.

Likewise, Eurofound (2017) in a descriptive study on the EU-28 countries demonstrates how an increase in social benefits has addressed inequality issues in Ireland, Hungary and Denmark. The study asserts that benefits withdrawal can adversely impact on inequality. These findings are also consistent with those of Raitano (2016) which notes that an increase in cash benefits has played a pivotal role in addressing inequality in the Nordic and Continental countries.

Nonetheless, a major critique against the above descriptive studies is that they conclude on the existence of causalities in the absence of rigorous statistical and econometric tests. Put differently, these studies make inferences on the basis of mere correlations provided by charts and trends. However, these correlations are insufficient to ascertain the impact of one variable on another. Additionally, the descriptive studies do not embark on any formal test in evaluating the impact of social benefits; some of them simply consider the difference between the gross and net measures of the Gini coefficient, however, this does not provide a clear picture about the effects of social benefits. Further, the Gini coefficient is the only inequality indicator considered by most of these studies. They largely ignore the income shares held by different income groups which could provide a broader viewpoint. Despite these obvious shortcomings, the descriptive studies made significant contributions in terms of data and analysis.

Having discussed the descriptive studies, this research now moves on to the studies that adopt more analytical and econometric approaches. Using LSDV, Obadić et al. (2014) evaluate how inequality responds to funds earmarked for social benefits in an annual data for EU-15 and EU-13 countries over the period 2000-2011. The results reveal that an increase in social benefit funds reduces inequality in the EU countries. However, the study of Obadic et al. (op. cit.) is plagued by a number of drawbacks. First, it relies solely on static model specifications which do not account for the persistence of inequality. Second, static models do not provide adequate information regarding the dynamic effects of social benefits across the EU. Third, endogeneity owing to potential reverse causality between social benefits and inequality is not robustly addressed. Fourth, no tests were reported to confirm that homoscedasticity and non-autocorrelation assumptions were met.

Likewise, Agnello et al. (2016) employ dynamic panel models implemented through an Instrumental Variables (IV) technique, they argue in favour of an increase in social benefits in their study on inequality in an annual data for the EU over the period 1980-2008. Specifically, their results support the need to address inequality through an increase in cash transfers and welfare payments. However, this study failed to provide any diagnostic tests confirming that the instruments utilized are valid and the dynamic model estimated is consistent. Nonetheless, 
the study deserves commendation for showing that results remain unchanged across a variety of inequality measures.

Similarly, Ball et al. (2013) employ a Panel-Corrected Standard Error (PCSE) estimator in their study on inequality over the period 1978-2009. The results also indicate that an increase in social benefits and transfers is essential in achieving a more equal distribution. Like most studies however, this study ignores the impact of social benefits on different income groups; which could provide a broader viewpoint. That notwithstanding, this study deserves credit for comprehensively distinguishing between the short and medium term impacts of spending cuts on inequality.

Using equivalent scales, Heady et al. (2001) also show that increases in social benefits generally reduced inequality in the EU in 1994. The result however clarifies that the impact of benefits varies considerably across the EU. Social benefits become more effective as countries increase the percentage of GDP spent on them. Heady et al. (op. cit.) go on to justify this argument with the impressive impacts of social benefits in countries which spend heavily on them; such as Denmark and the Netherlands. Nonetheless, a shortcoming of this study arises from the fact that equivalence scales seem intuitive theoretically but have a number of limitations when used in practice. Specifically, there is no unanimous agreement in the literature as to how to decide on an appropriate scale and how weights should be calculated (Haughton \& Khandker, 2009).

Likewise, Dafermos and Papatheodorou (2012) utilize fixed and random effects estimators, they argue in support of an increase in social benefits in their study on the role of institutions in inequality reduction in the EU over the period 1994-2008. The results reveal that cash transfers are generally vital in reducing the gap between the rich and the poor. The study clarifies that the usefulness of these transfers is conditioned on how efficiently the social protection system is organized. Nonetheless, this study fails to consider key determinants of inequality such as finance, trade openness and economic integration. If these omitted variables are correlated with the included explanatory variables, endogeneity arises.

Using data spanning between 1970 and 2013, Arestis and Phelps (2018) investigate the inequality implications of the European Monetary Union (EMU) over the period 1970-2013. A crucial finding of the study suggests that an increase in national social protection expenditure has a significantly negative impact on inequality. The study went on to show that cuts in the expenditure would have adverse effects on the income distribution especially in the absence of the European Social Fund. This result is consistent with the findings of Bertola (2010) which indicates that the gap between the rich and the poor was further widened by a reduction in social spending among European countries between 1995 and 2005.

\subsubsection{Studies That Find a Positive Impact of Social Benefits on Inequality}

The studies that find a positive impact of social benefits are also classified into descriptive and econometric studies. Some of the descriptive studies support austerity measures and argue against an increase in social benefits. These studies argue that an increase in government spending in the face of EU countries' rising public debts would only increase 
inequality especially if a few rich creditors hold the debts. Atkinson (2013) adopts a descriptive approach in addressing inequality issues in Europe. The study argues that inequality in Europe can be addressed by austerity measures especially those implemented through an increase in progressive taxes. The suggestions of Atkinson (op. cit.) are consistent with those of OECD (2017) although the latter goes a step further by clarifying that the extent to which an increase in tax can address inequality in Europe depends on how efficiently the welfare systems are managed. Nonetheless, the above studies are also plagued by the previously discussed draw backs that are generally associated with descriptive studies.

Turning to the studies that adopt econometric approaches, some of them argue against an increase in social benefits based on the dependency syndrome argument which suggests that the programmes may encourage the low income recipients to be overly reliant on the handouts; this could result in a decrease in their working hours compared to high income earners. Consequently, the gap between the rich and the poor continues to widen. This argument is consistent with the findings of Niehues (2010) in a study on the impact of more targeted benefits on inequality in the EU over the period 1993-2007. However, this study only considers inequality at an aggregate level; it fails to consider how benefits affect individuals in different economic situations. Hence, it provides a rather narrow appraisal of the role of benefits in inequality reduction.

Similarly, the studies of Butler and Kondratas (1987), Lee (1987) Murray (1984) argue against an increase in social benefits because they induce poor low skilled workers to live on the handouts rather than take up low-paying jobs. They further argue that the social benefits are insufficient to take these workers out of poverty and this causes them to remain perpetually poor; consequently, the gap between the rich and the poor widens. Yet, this gap could be reduced in the absence of the handouts as such low skilled workers would be compelled to take up entry-level jobs through which they may advance up the job ladder and ultimately avoid poverty.

Likewise, Meyer (2002) and Barr (2004) both show that some benefits discourage recipients from working and the resultant effect of an increase in these benefits can be a more unequal income distribution. This argument is also supported by Bergh (2005) which asserts that means-tested benefits increase inequality because they have a greater impact in discouraging low income workers from participating actively in the labour market relative to high income workers.

\subsubsection{Studies That Reach Less Straightforward Conclusions}

While some of these studies adopt a descriptive approach, others adopt an econometric approach. Heady et al. (2001) adopt a descriptive approach in appraising the relevance of social security programmes in the EU. The findings from the study reveal that the existence of many determinants of inequality complicates the relationship between the percentage of GDP spent on social benefits and inequality. The relationship is also determined by factors such as: the degree to which the low income groups benefit from the social benefits, how funds have been allocated across social security programmes, and the extent to which social benefits are targeted. 
Likewise, the descriptive approach adopted by Arestis and Gonzalez-Martinez (2016) lead them to conclude that a decrease in inequality requires not just an increase in social benefits but also sound monetary policies, labour protection legislations and policies that promote financial stability. Again, the above works can be criticized on the basis of the previously discussed draw backs associated with studies that adopt descriptive approaches.

Moving on to the studies that adopt econometric approaches; Fuest et al. (2010) adopt sequential accounting and factor source decomposition approaches in examining the impacts of social benefits on inequality in the enlarged EU. While results from the former approach indicate that an increase in social benefits contributes significantly towards reducing inequality, the latter approach indicates that an increase in social benefits aggravates inequality. A plausible reason for these contradictory results may be connected with the fact that the two approaches utilized are built on diametrically opposite normative views.

Likewise, Bargain et al. (2017) obtain mixed results in a study on the impact of social benefits on income redistribution in selected European countries over the period 2008-2013. According to the study, an increase in social benefit in the UK reduces inequality while the case appeared to be the other way round for Ireland following the 2007-2009 crisis. Nonetheless, this study employs microsimulation which has a number of drawbacks; the most notable of which is that it violates basic theoretical principles. Additionally, the approach relies on extremely rigorous and high-quality data which are often unavailable (Klevmarken, 1997).

Employing cross-sectional and panel data analyses, Rodríguez-Pose and Fratesi (2004) investigate the relationship between European social policies and social cohesion; findings from the study suggest that social policies have an insignificant impact on regional inequality. This result also corroborates the findings of Barro (1999) in his study on the relationship between inequality, growth and investment; the study asserts that transfers -although- have an effect on regional inequality, their precise impact is elusive.

Overall, there exists a debate in the literature regarding the impact of social benefits on inequality.

\subsection{Scope for Contributions}

Three major gaps can be identified in the literature. The first gap is related with the fact that no existing work -to the knowledge of this study- investigates the impact of social benefits on the income shares of different income groups. Such a research is crucial because the Gini coefficient only provides information about the gap between the rich and the poor; it provides little or no information about the distance between vaguely defined income groups such as the working class and the middle income class (Hayes \& Vidal, 2015). Additionally, the study of the income groups makes it possible to ascertain whether the benefits have been pro-poor, pro-middle class or pro-rich. The second gap in the literature has to do with the fact that no study investigating the impact of social benefits employs static and dynamic methods in addressing issues related to endogeneity, heterogeneity and inequality persistence. The use of static and dynamic methods makes results robust and rigorous as well as facilitates 
comparison. The third gap is connected with the omission of some key determinants of inequality in many studies.

Accordingly, this study fills the gaps by considering the impacts of social benefits on the low, middle and high income groups. The income groups are represented by the income shares of six different income percentiles. Likewise, three estimation techniques are adopted. Specifically, this research employs POLS which includes control variables that account for potential endogeneity due to the omission of observed heterogeneity. Also, this study employs LSDV which includes country and time fixed effect that account for potential endogeneity arising from the omission of unobserved heterogeneity. Thereafter, this research employs the GMM-IV estimator of Arellano and Bond (1991) which accounts for inequality persistence and potential endogeneity arising from reverse causality. Finally, this study advances the literature by considering determinants of inequality such as finance, employment protection legislation and trade union density.

\section{Methodology and Data}

\subsection{Empirical Models}

Although the methods underlying this study are similar to those of Obadic et al. (2014) and Beetsma et al. (2012), the contributions of this research differ from those of these studies. Unlike both studies, this study provides a broader appraisal by identifying the impact of benefits not only on the aggregate level of inequality but also on the income shares of different income groups. Likewise, Obadić et al. (op. cit.) rely solely on static fixed and random effect panel regression models which fail to adequately control for the persistence of inequality and do not provide sufficient information regarding the dynamic effects of social benefits all through the EU. Beetsma et al. (op. cit.) on the other hand employ a dynamic panel regression model but fail to address the transmission channel through which social benefits impact on income redistribution. In this study, both static and dynamic methods are employed to facilitate comparison and ensure robust results. This research employs POLS which controls for observed heterogeneity, LSDV which goes a step further by accounting for unobserved heterogeneity, and finally the dynamic GMM-IV estimator of Arellano and Bond (1991) which controls for inequality persistence and endogeneity.

\subsubsection{Static Model Specification}

Equation (1) represents the static model specification. For each country i, Inequality ${ }_{i t}$ is the relevant inequality indicator observed at time $t$. Benefits $s_{i t}$ is the variable that captures social benefits. $Z_{\mathrm{it}}$ represents the set of control variables. Similarly, $\mu_{\mathbf{i}}$ and $\theta_{\mathrm{t}}$ respectively capture the unobserved country and time fixed effects:

$$
\begin{aligned}
\text { Inequality }_{i t} & =\alpha+\beta \text { Benefits }_{i t}+\gamma Z_{i t}+\varepsilon_{i t} \\
\varepsilon_{i t} & =\mu_{i}+\theta_{t}+v_{i t}
\end{aligned}
$$

While $\beta$ represents the coefficient associated with Benefits ${ }_{i t} ; \gamma$ represents the set of coefficients associated with the control variables; and the error term, $v_{i t}$ represents the residual variation. This study also assumes that the error term is a white noise (stationary) 
process with zero mean and constant variance. Further description of the inequality indicators, the social benefits variable and the control variables is provided in Section 3.5.

\subsubsection{Dynamic Model Specification}

Being a dynamic model, equation (2) makes it possible to distinguish between the long and short run impacts of social benefits on the inequality indicators:

$$
\begin{aligned}
\text { Inequality }_{i t} & =\alpha+\lambda \text { Inequalit }_{i t-1}+\beta \text { Benefits }_{i t}+\gamma Z_{i t}+\varepsilon_{i t} \\
\varepsilon_{i t} & =\mu_{i}+\theta_{t}+v_{i t}
\end{aligned}
$$

In equation (2), the inequality persistence phenomenon is illustrated by some unobserved factors which prevent inequality from changing drastically from year to year. These unobserved factors are thus accounted for by the lagged dependent variable since it contains information regarding the past of the explanatory variables. The extent to which inequality is characterized by persistence is highlighted by the sign, size and significance of the lagged dependent variable's coefficient; $\lambda$.

In evaluating the impact of social benefits on the different income groups; equations (1) and (2) are applied across the income shares held by different income percentiles.

\subsection{Testable Hypotheses}

This study draws on the theoretical literature to form its hypotheses regarding the coefficient associated with the social benefit variable; $\beta$. In section 2 , this study discussed various theories which confirm that social benefits have a significant impact on inequality. While the political economy-growth model of Alesina and Perotti (1994) predicts a negative impact, a positive impact is predicted by the median voter model of Meltzer and Richard (1981) as well as hypotheses based on the mainstream labour supply theory (Aaberge \& Colombino, 2006). Due to the ambiguity posed by these different outcomes, a two tailed test is employed.

The null hypothesis $\left(\mathrm{H}_{0}\right)$ is that social benefits do not have any significant impact on the inequality variables $(\beta=0)$,

The alternative hypothesis $\left(\mathbf{H}_{1}\right)$ is that social benefits have a significant impact on the inequality variables $(\beta \neq 0)$.

\subsection{Endogeneity Issues}

Firstly, endogeneity may arise from the fact that the relationship between social benefits and inequality is usually characterized by reverse causality. In other words, inequality impacts on social benefits just as social benefits impact on inequality. This reverse causality is well justified by the median voter model of Meltzer and Richard (1981) as well as findings from existing studies (see, for example, Iosifidi \& Mylonidis, 2017; Salotti \& Trecroci 2015). Secondly, endogeneity may arise when there exists an omitted variable that is correlated with the explanatory variables in the model. Thirdly, endogeneity may be an issue when variables are not captured by appropriate proxies and the resulting measurement errors are correlated with the included explanatory variables. If endogeneity is not properly addressed, the 
parameter estimates would not be consistent and the impact of social benefits on inequality could either be overstated or understated.

In addressing endogeneity, this study firstly estimates equation (1) using POLS and LSDV estimators. POLS includes control variables and hence accounts for potential endogeneity arising from the omission of observed heterogeneity. LSDV however improves on POLS by including country and time fixed effects that control for potential endogeneity arising from the omission of unobserved heterogeneity. Secondly, equation (2) is estimated using the GMM-IV estimator; being a dynamic Instrumental Variables (IV) technique, this estimator deals with inequality persistence and potential endogeneity arising from reverse causality. Hence, the GMM-IV estimator has some desirable properties not found in POLS and LSDV. Likewise preference is given to the GMM-IV estimator over a dynamic fixed LSDV since the latter is likely to be biased. Compared to the existing literature, the modelling strategy adopted in this study provides a more robust approach vis-a-vis addressing endogeneity issues.

\subsection{Sample Selection}

This study examines the impact of social benefits on income-inequality in an unbalanced panel of the EU-15 countries for the period 1995-2015. The EU-15 countries are: Belgium, Germany, Ireland, Greece, Spain, France, Italy, Luxembourg, Denmark, Sweden, Netherlands, Austria, Portugal, Finland and the United Kingdom. The time span covered by this study is determined by the homogeneous data available from Eurostat's - EU Statistics on Income and Living Conditions Survey.

Annual data is employed in this study because quarterly and monthly data on inequality with reasonably long time-spans are unavailable for all the countries. It is also well established in the literature to employ annual data in investigating the relationship between social benefits and inequality. Hence, the use of annual data helps to increase comparability.

Within the context of this study, panel data is superior to time series data because the latter can only provide country specific inequality functions for each of the EU-15 countries making it impossible to obtain any information about other countries that are similar to these countries in terms of economic and financial institutions. Additionally, in estimating dynamic models in time series analysis, the need to address potential collinearity between current and lagged variables requires restrictions such as those provided by Koyck (1954) and Almon (1965). However, in panel data analyses, the collinearity can be easily addressed through the inter-country heterogeneity (Griliches, 1967; Pakes \& Griliches, 1984). Further, the study of Hsiao et al. (1993) indicates that when there is no substantial difference among the countries under consideration, it is possible to obtain more accurate predictions regarding a country by observing other countries using panel data.

Panel data is also superior to cross sectional data because it increases the dimension of estimation, allows for the control of heterogeneity and accounts for policy effects which alter inequality over time rather than across space. Additionally, a panel data analyses within the context of this study would contain more sample variability and degrees of freedom. As noted 
by Hsiao et al. (1995), this makes the parameter estimates obtained from panel data analyses to be more reliable and efficient.

\subsection{Variable Selection}

\subsubsection{Dependent Variables}

\subsubsection{Gini Coefficient}

In determining the impact of social benefits on inequality, the dependent variable is represented by the Gini coefficient (Inequality ito $_{0}$ ) of equivalised disposable income. The values of the Gini coefficient (Inequality $\mathrm{it0}_{\mathrm{i}}$ ) in this study range between 0 and 100 . Generally, the Gini coefficient is computed by comparing the cumulative share of a population and the cumulative share of the incomes received by the population (OECD, 2018a). Data are sourced from Eurostat's - EU Statistics on Income and Living Conditions Survey. The Gini coefficient is the most popular and widely used measure of inequality in the literature. Additionally, it satisfies many of the widely accepted properties expected of an income-inequality measure as identified by Foster et al. (2013). Further, the Gini coefficient of equivalised disposable income is utilized because it is an after tax measure of inequality. In other words, it captures inequality in disposable terms. This is necessary because this study focuses on the impacts of social benefits and hence after tax measures are more relevant than market measures.

\subsubsection{Income Percentiles}

In investigating the impact of social benefits on different income groups, the dependent variable is represented by the share of the national income held by families in six different income percentiles. While the low income earners are represented by the 10th percentile ( Inequality $\mathrm{it}_{1}$ ) and 20th percentile (Inequality $\mathrm{it}_{\mathrm{it}}$ ), the middle-income earners are represented by the 40 th percentile (Inequality ${ }_{i t 3}$ ) and 60 th percentile (Inequality it4 $_{4}$ ) and the wealthy income earners are represented by the 80th percentile (Inequality it5 $_{\text {) }}$ ) and 90th percentile (Inequality ${ }_{i t 6}$ ). It is necessary to consider various income percentiles because the Gini coefficient only provides information about the income gap between the rich and the poor, it does not provide any comprehensive information about the income gap between subtly defined income groups such as the working class and the middle income class (Hayes and Vidal, 2015). Additionally, the use of income percentiles makes it possible to determine whether the social benefits are pro-poor, pro-middle class or pro-rich. Data are sourced from Eurostat's - EU Statistics on Income and Living Conditions Survey.

\subsubsection{Primary Explanatory Variable}

Social Benefits (Benefits it $_{\text {) }}$ represents the primary explanatory variable; they refer to those expenditures that are directed towards the benefit of the society. They usually take the form of cash benefits, provision of goods in kind as well as tax exemptions intended for societal benefits. The benefits may be directed towards the poor, the sick, retired workers, youths as well as those who are unemployed (OECD, 2018b). This variable is measured as a percentage of GDP and this ensures that it is captured in real terms and not in nominal terms. Data are 
retrieved from the OECD database on Tax and Social Expenditure Statistics.

\subsubsection{Control Variables}

\subsubsection{Per Capita GDP}

Per capita GDP ( $\left.\mathrm{GDP}_{\mathrm{it}}\right)$ is measured as the ratio of the gross domestic product to the midyear population. This variable is scaled in constant 2010 US Dollars and hence measured in real terms. Data are sourced from World Bank's World Development Indicators. This study's expectation regarding per capita GDP is based on Kuznets inverted-U hypothesis, which posits that there exists a non-linear relationship between the income level and inequality (Kuznets, 1955). When the income level is low, it would be positively related with inequality, and when a country develops and the income level increases up to a given point, the relationship turns negative. The logarithmic transformations of per capita GDP (GDP it $_{\text {) }}$ and square of per capita GDP (GDP it $)$ are used.

\subsubsection{Finance}

Finance (Finance it $_{\text {it }}$ ) is captured from the perspective of financialization using Stock Market Capitalization (SMC). SMC is calculated by multiplying the share price by the number of shares that are outstanding in listed companies (World Bank, 2018b). Data are sourced from World Bank's World Development Indicators. The impact of finance on inequality is ambiguous. Some theories predict that an increase in finance would provide less privileged individuals with better access to financial services and ultimately reduce inequality (Becker \& Tomes, 1979). However, some other theories suggest that the benefits of an improved financial system may accrue solely to the high income groups and consequently result in a more unequal distribution (Greenwood \& Jovanovic, 1990).

\subsubsection{Economic Integration}

Economic integration $\left(\mathrm{EI}_{\mathrm{it}}\right)$ measures the share of a country's exports to $\mathrm{EU}$ countries in its total exports. It is otherwise known as the intra-regional trade share (Eurostat, 2018). Data are sourced from Eurostat's survey on Intra and Extra-EU trade. This variable is included on the basis of the factor price equalization theorem of Samuelson (1953) which indicates that an increase in economic integration ensures convergence and ultimately reduces inequality (Ghosh \& Faber, 2010).

\subsubsection{Technological Development}

Technological development $\left(\mathrm{TD}_{\mathrm{it}}\right)$ is measured by the percentage of a country's gross domestic product that is incurred on current and capital expenditures on Research and Development (R\&D) in business, education, private and government sectors (World Bank; 2016). It is scaled as a percentage of GDP. Data are sourced from World Bank's World Development Indicators. This study's expectation regarding technological development derives from Solow's skill-biased technological change model which suggests that technological advancement can widen the wage gap between skilled and unskilled workers (Solow, 1957). This argument is based on the supposition that technology has a higher impact in increasing the demand for skilled workers relative to unskilled workers. The aftermath of 
this is an increase in wage inequality.

\subsubsection{Trade Union Density}

Trade union density $\left(\mathrm{TUD}_{\mathrm{it}}\right)$ measures the share of trade union members within all wage earners (OECD, 2016). Data are extracted from OECD Employment and Labour Market Statistics on Trade Union Density. This variable is included on the basis of those hypotheses which suggest that trade union density has a negative impact on inequality; based on the prey and predator models of Lotka (1925) and Volterra (1931).

\subsubsection{Trade Openness}

Trade openness $\left(\mathrm{TO}_{\mathrm{it}}\right)$ is represented by the ratio of a country's exports and imports combined; to its gross domestic product (World Bank, 2016). It is scaled as a percentage of GDP. Data are sourced from World Bank's World Development Indicators. This variable is included on the basis of the Heckscher-Ohlin (HO) theory which suggests that as a country becomes more open to trade, the demand and price of its abundant factors increase (Heckscher, 1919; Ohlin, 1933). Consequently, the income share held by the abundant factors also increases. Nonetheless, if other than the high income groups happen to be the beneficiaries of trade openness, inequality would likely reduce (Anderson, 2005).

\subsubsection{Unemployment}

The unemployment rate (Unemployment $t_{i t}$ ) is measured in accordance with the definition provided by the International Labour Organization (ILO). Hence, it captures the number of unemployed individuals expressed as a percentage of the labour force. The labour force comprises all individuals that are willing and able to work (ILO, 1982). Unemployment is measured in percentage terms. Data are from Eurostat's General and Regional Statistics on Unemployment Rate. Although the impact of unemployment on inequality is ambiguous, the hypothesis that unemployment increases inequality is more popular in the literature (Gustafsson \& Johansson, 1997; Parker; 1999). This hypothesis rests on the assumption that the low income unskilled workers make up a majority of those who get laid off during periods of high unemployment, as such, the reduction in their earnings increases inequality (Blank \& Card, 1993).

\subsubsection{Progressive Tax}

The progressive taxes $\left(\mathrm{PT}_{\mathrm{it}}\right)$ considered are a group of recurring and non-recurring charges levied on the use, transfer or inheritance of the net wealth of an individual or a corporation

(OECD, 2018c). It is scaled as a percentage of GDP. Data are sourced from the OECD

Database on Tax Revenue. This study's expectation regarding progressive tax is based on Jakobsson-Fellman theorem which suggests that the gap between the rich and the poor can only be reduced through effective use of progressive taxes (Jakobsson, 1976; Fellman, 1976).

\subsection{Summary Statistics}

Table 1 provides a descriptive statistics of the Gini index and the income percentiles representing different income groups. 
Table 1. Summary statistics

\begin{tabular}{lllllll}
\hline Variable & $\mathrm{N}$ & Mean & SD & AR(1) & Minimum & Maximum \\
\hline Gini coefficient & 286 & 29.233 & 3.780 & 0.957 & 20.000 & 38.100 \\
10th percentile & 273 & 3.181 & 0.675 & 0.880 & 1.400 & 5.000 \\
20th percentile & 273 & 5.174 & 0.604 & 0.935 & 4.000 & 6.200 \\
40th percentile & 273 & 7.252 & 0.499 & 0.923 & 6.000 & 8.300 \\
60th percentile & 273 & 9.329 & 0.383 & 0.812 & 8.000 & 10.100 \\
80th percentile & 273 & 12.137 & 0.357 & 0.776 & 11.000 & 13.000 \\
90th percentile & 273 & 14.540 & 0.646 & 0.892 & 13.000 & 16.000
\end{tabular}

Source: Author's own computation using data from Eurostat, EU Statistics on Income and Living Conditions Survey.

Note: SD represents the standard deviation and AR(1) represents the first-order autocorrelation coefficient.

As seen in Table 1, the higher the percentile, the higher is the income share held. As a corollary, the income share of the 90th percentile is higher than that of other percentiles considered in this study. Likewise, the first-order autocorrelation coefficients are positive and large in size further indicating a high degree of inequality persistence. This also justifies the use of the GMM-IV estimator to account for the persistence. Although the 10th percentile holds the least share of income, dispersion in income shares is paradoxically highest within this percentile. Likewise, the standard deviations on the inequality variables reveal that there may be heterogeneity across the EU-15 countries. Nonetheless, the LSDV used in this study accounts for this through country and time fixed effects.

\section{Empirical Analysis and Discussion of Results}

\subsection{Main Results}

\subsubsection{Results on Social Benefits from POLS, LSDV and GMM-IV Estimators}

In order to make this research robust and comparable to existing studies, POLS and LSDV techniques are used to estimate the static models. This study addresses the issues of heteroscedasticity and autocorrelation by employing Newey-West standard errors (Newey \& West, 1987). Additionally, this study tests for stationarity using Phillips-Perron unit root test, and the results confirm that all the key variables are stationary at level (Phillips \& Perron, 1988). The test is conducted with an intercept but no trend Table 2 reports the regression of the inequality variables on the explanatory variables using POLS technique. The result indicates that a given increase in social benefits would result in a 0.095 fall in the Gini coefficient. In terms of standard deviation changes, the result suggests that a 0.378 decrease in the Gini coefficient is expected with a one standard deviation increase in social benefits. Similarly, a one standard deviation increase in social benefits leads to 0.100 standard deviation decrease in the Gini coefficient. Nonetheless, this result should be interpreted with caution as it is not statistically significant. As regards the income groups, social benefits have a mixed impact on the low income groups, positive impact on the middle income groups and negative impact on the high income groups. Again, most of these results are not statistically significant. 
Table 3 shows the results when LSDV is used to account for fixed effects. The significant p-values for the fixed effects confirm the need to control for heterogeneity across space and time. Likewise, the adjusted R-squared statistics obtained for the LSDV are all greater than those of the POLS, hence, a greater amount of the variation in the inequality variables is explained by the LSDV technique. Further, POLS and LSDV are compared using Hausman test (Hausman, 1978) and for all regressions, the results suggest that the null hypothesis that POLS is consistent be rejected, indicating that the results of POLS are affected by endogeneity potentially due to the omission of fixed effects. Expectedly, there exist some differences between the LSDV and POLS results. With the LSDV, the negative impact of social benefits on the Gini coefficient increases in size and becomes statistically significant at $5 \%$ level. The result indicates that a given increase in social benefits would result in a 0.482 fall in the Gini coefficient. In terms of standard deviation changes, the result suggests that a 1.918 decrease in the Gini coefficient is expected with a one standard deviation increase in social benefits. Similarly, a one standard deviation increase in social benefits leads to 0.507 standard deviation decrease in the Gini coefficient. This result is in line with the political economy-growth model of Alesina and Perotti (1994) which suggests that an increase in social benefits is effective in reducing inequality. Also, some interesting results are obtained from the regression of the different income groups on social benefits. The impact of social benefits on the low income groups becomes significantly positive and its negative impact on the high income groups becomes significant and increases in absolute terms.

Table 2. Social benefits and income inequality: POLS estimator.

\begin{tabular}{|c|c|c|c|c|c|c|c|}
\hline & Gini & (P10) & (P20) & (P40) & (P60) & (P80) & (P90) \\
\hline Benefits $_{\text {it }}$ & $\begin{array}{l}-0.095 \\
(0.070)\end{array}$ & $\begin{array}{l}-0.002 \\
(0.013)\end{array}$ & $\begin{array}{l}0.015 \\
(0.011)\end{array}$ & $\begin{array}{l}0.020^{* *} \\
(0.010)\end{array}$ & $\begin{array}{l}0.002 \\
(0.009)\end{array}$ & $\begin{array}{l}-0.009 \\
(0.010)\end{array}$ & $\begin{array}{l}-0.017 \\
(0.012)\end{array}$ \\
\hline TUD $_{\text {it }}$ & $\begin{array}{l}-0.029 * * * \\
(0.010)\end{array}$ & $\begin{array}{l}-0.001 \\
(0.003)\end{array}$ & $\begin{array}{l}0.002 \\
(0.002)\end{array}$ & $\begin{array}{l}0.004 * * * \\
(0.001)\end{array}$ & $\begin{array}{l}0.010^{* * * *} \\
(0.002)\end{array}$ & $\begin{array}{l}0.006^{*} \\
(0.003)\end{array}$ & $\begin{array}{l}-0.001 \\
(0.003)\end{array}$ \\
\hline $\mathrm{PT}_{\text {it }}$ & $\begin{array}{l}0.006 \\
(0.275)\end{array}$ & $\begin{array}{l}0.143^{* * * *} \\
(0.048)\end{array}$ & $\begin{array}{l}-0.004 \\
(0.044)\end{array}$ & $\begin{array}{l}-0.040 \\
(0.037)\end{array}$ & $\begin{array}{l}-0.028 \\
(0.034)\end{array}$ & $\begin{array}{l}-0.069 * \\
(0.038)\end{array}$ & $\begin{array}{l}-0.098^{* * *} \\
(0.048)\end{array}$ \\
\hline $\mathrm{GDP}_{\text {it }}$ & $\begin{array}{l}14.320 \\
(13.954)\end{array}$ & $\begin{array}{l}3.677^{*} \\
(1.919)\end{array}$ & $\begin{array}{l}-1.878 \\
(2.020)\end{array}$ & $\begin{array}{l}-3.426^{*} \\
(1.808)\end{array}$ & $\begin{array}{l}-2.198 \\
(1.853)\end{array}$ & $\begin{array}{l}-0.836 \\
(1.738)\end{array}$ & $\begin{array}{l}2.810 \\
(2.158)\end{array}$ \\
\hline $\mathrm{GDP}_{\mathrm{it}}^{2}$ & $\begin{array}{l}-0.783 \\
(0.758)\end{array}$ & $\begin{array}{l}-0.196 * \\
(0.103)\end{array}$ & $\begin{array}{l}0.103 \\
(0.109)\end{array}$ & $\begin{array}{l}0.186^{*} \\
(0.098)\end{array}$ & $\begin{array}{l}0.118 \\
(0.100)\end{array}$ & $\begin{array}{l}0.043 \\
(0.094)\end{array}$ & $\begin{array}{l}-0.154 \\
(0.116)\end{array}$ \\
\hline Unemployment $_{\text {it }}$ & $\begin{array}{l}0.061 \\
(0.062)\end{array}$ & $\begin{array}{l}-0.044^{* * *} \\
(0.010)\end{array}$ & $\begin{array}{l}-0.019 * * \\
(0.009)\end{array}$ & $\begin{array}{l}-0.002 \\
0.007\end{array}$ & $\begin{array}{l}0.012 * \\
(0.007)\end{array}$ & $\begin{array}{l}0.032^{* * *} \\
(0.009)\end{array}$ & $\begin{array}{l}.035^{* * *} \\
(0.013)\end{array}$ \\
\hline Finance $_{\text {it }}$ & $\begin{array}{l}-0.001 \\
(0.009)\end{array}$ & $\begin{array}{l}-0.000 \\
(0.001)\end{array}$ & $\begin{array}{l}0.000 \\
(0.001)\end{array}$ & $\begin{array}{l}0.000 \\
(0.001)\end{array}$ & $\begin{array}{l}0.000 \\
(0.001)\end{array}$ & $\begin{array}{r}0.001 \\
(0.001)\end{array}$ & $\begin{array}{l}0.001 \\
(0.001)\end{array}$ \\
\hline $\mathrm{TO}_{\text {it }}$ & $\begin{array}{l}-0.000 \\
(0.009)\end{array}$ & $\begin{array}{l}0.004^{* * * *} \\
(0.001)\end{array}$ & $\begin{array}{l}-0.000 \\
(0.001)\end{array}$ & $\begin{array}{l}-0.001 \\
(0.001)\end{array}$ & $\begin{array}{l}-0.001 \\
(0.001)\end{array}$ & $\begin{array}{l}-0.000 \\
(0.001)\end{array}$ & $\begin{array}{l}0.000 \\
(0.001)\end{array}$ \\
\hline $\mathrm{EI}_{\mathrm{it}}$ & $\begin{array}{l}-0.085^{* * *} \\
(0.029)\end{array}$ & $\begin{array}{l}0.007 \\
(0.005)\end{array}$ & $\begin{array}{l}0.013^{* *} \\
(0.005)\end{array}$ & $\begin{array}{l}0.011^{\text {**** }} \\
(0.004)\end{array}$ & $\begin{array}{l}0.000 \\
(0.004)\end{array}$ & $\begin{array}{l}-0.008^{*} \\
(0.004)\end{array}$ & $\begin{array}{l}-0.009 * \\
(0.006)\end{array}$ \\
\hline $\mathrm{TD}_{\text {it }}$ & $\begin{array}{l}-2.357 * * * \\
(0.379)\end{array}$ & $\begin{array}{l}0.626^{* * * *} \\
(0.090)\end{array}$ & $\begin{array}{l}0.392 * * * \\
(0.063)\end{array}$ & $\begin{array}{l}0.216 * * * \\
(0.056)\end{array}$ & $\begin{array}{l}0.075 \\
(0.060)\end{array}$ & $\begin{array}{l}-0.218^{* * *} \\
(0.074)\end{array}$ & $\begin{array}{l}-0.436 \\
(0.078)\end{array}$ \\
\hline Constant $(\alpha)$ & $\begin{array}{l}-21.117 \\
(62.997)\end{array}$ & $\begin{array}{l}-15.629^{*} \\
(8.740)\end{array}$ & $\begin{array}{l}11.405 \\
(9.115)\end{array}$ & $\begin{array}{l}21.029 * * * \\
(8.175)\end{array}$ & $\begin{array}{l}18.772 * * \\
(8.357)\end{array}$ & $\begin{array}{l}16.945^{* * *} \\
(7.909)\end{array}$ & $\begin{array}{l}3.780 \\
(9.760)\end{array}$ \\
\hline Number of observations & 122 & 122 & 122 & 122 & 122 & 122 & 122 \\
\hline Adjusted R squared & 0.657 & 0.656 & 0.660 & 0.637 & 0.351 & 0.456 & 0.648 \\
\hline p-value for model significance & 0.000 & 0.000 & 0.000 & 0.000 & 0.000 & 0.000 & 0.000 \\
\hline
\end{tabular}

Source: Author's own computation based on data described in section 3 .

Note: The parentheses contain the standard errors. ${ }^{*} \mathrm{p}<.10 .{ }^{*} \mathrm{p}<.05 . * * * \mathrm{p}<.01$. 
Table 3. Social benefits and income inequality: LSDV estimator.

\begin{tabular}{|c|c|c|c|c|c|c|c|}
\hline & Gini & (P10) & (P20) & (P40) & (P60) & (P80) & (P90) \\
\hline Benefits $_{\text {it }}$ & $\begin{array}{l}-0.482 * * \\
(0.247)\end{array}$ & $\begin{array}{l}0.133 \text { *** } \\
(0.039)\end{array}$ & $\begin{array}{l}0.078 \text { *** } \\
(0.030)\end{array}$ & $\begin{array}{l}0.019 \\
(0.031)\end{array}$ & $\begin{array}{l}-0.015 \\
(0.030)\end{array}$ & $\begin{array}{l}-0.037^{*} \\
(0.024)\end{array}$ & $\begin{array}{l}-0.073 * * \\
(0.034)\end{array}$ \\
\hline TUD $_{\text {it }}$ & $\begin{array}{l}0.173^{*} \\
(0.101)\end{array}$ & $\begin{array}{l}-0.024 \\
(0.021)\end{array}$ & $\begin{array}{l}-0.015 \\
(0.012)\end{array}$ & $\begin{array}{l}0.001 \\
(0.014)\end{array}$ & $\begin{array}{l}-0.020^{*} \\
(0.013)\end{array}$ & $\begin{array}{l}-0.050^{* * * *} \\
(0.014)\end{array}$ & $\begin{array}{l}0.010 \\
(0.017)\end{array}$ \\
\hline $\mathrm{PT}_{\text {it }}$ & $\begin{array}{l}0.451 \\
(0.460)\end{array}$ & $\begin{array}{l}0.069 \\
(0.111)\end{array}$ & $\begin{array}{l}-0.003 \\
(0.055)\end{array}$ & $\begin{array}{l}-0.046 \\
(0.063)\end{array}$ & $\begin{array}{l}-0.021 \\
(0.066)\end{array}$ & $\begin{array}{l}-0.122 * * \\
(0.061)\end{array}$ & $\begin{array}{l}-0.202 * * * \\
(0.078)\end{array}$ \\
\hline $\mathrm{GDP}_{\text {it }}$ & $\begin{array}{l}-55.963 \\
(118.514)\end{array}$ & $\begin{array}{l}1.824 \\
(26.756)\end{array}$ & $\begin{array}{l}31.00 * * \\
(13.952)\end{array}$ & $\begin{array}{l}6.412 \\
(15.565)\end{array}$ & $\begin{array}{l}5.177 \\
(14.696)\end{array}$ & $\begin{array}{l}27.748^{* *} \\
(13.683)\end{array}$ & $\begin{array}{l}22.157 \\
(21.901)\end{array}$ \\
\hline $\mathrm{GDP}_{\mathrm{it}}^{2}$ & $\begin{array}{l}3.252 \\
(5.713)\end{array}$ & $\begin{array}{l}-0.071 \\
(1.288)\end{array}$ & $\begin{array}{l}-1.515 * * \\
(0.669)\end{array}$ & $\begin{array}{l}-0.366 \\
(0.742)\end{array}$ & $\begin{array}{l}-0.379 \\
(0.695)\end{array}$ & $\begin{array}{l}-1.458 * * \\
(0.655)\end{array}$ & $\begin{array}{l}-1.094 \\
(1.046)\end{array}$ \\
\hline Unemployment $_{\text {it }}$ & $\begin{array}{l}0.170^{* *} \\
(0.088)\end{array}$ & $\begin{array}{l}-0.045 * * * \\
(0.017)\end{array}$ & $\begin{array}{l}-0.011 \\
(0.011)\end{array}$ & $\begin{array}{l}-0.006 \\
(0.011)\end{array}$ & $\begin{array}{l}-0.011 \\
(0.010)\end{array}$ & $\begin{array}{l}0.001 \\
(0.010)\end{array}$ & $\begin{array}{l}0.008 \\
(0.016)\end{array}$ \\
\hline Finance $_{\text {it }}$ & $\begin{array}{l}-0.003 \\
(0.007)\end{array}$ & $\begin{array}{l}0.003^{* * *} \\
(0.001)\end{array}$ & $\begin{array}{l}-0.000 \\
(0.000)\end{array}$ & $\begin{array}{l}-0.000 \\
(0.001)\end{array}$ & $\begin{array}{l}0.000 \\
(0.001)\end{array}$ & $\begin{array}{r}0.000 \\
(0.001)\end{array}$ & $\begin{array}{l}0.001 \\
(0.001)\end{array}$ \\
\hline $\mathrm{TO}_{\text {it }}$ & $\begin{array}{l}-0.025 * * * \\
(0.009)\end{array}$ & $\begin{array}{l}0.001 \\
(0.002)\end{array}$ & $\begin{array}{l}0.002 * * \\
(0.001)\end{array}$ & $\begin{array}{l}0.003 * * \\
(0.001)\end{array}$ & $\begin{array}{l}0.004 * * * \\
(0.001)\end{array}$ & $\begin{array}{l}0.003 * * \\
(0.001)\end{array}$ & $\begin{array}{l}0.002 * \\
(0.001)\end{array}$ \\
\hline $\mathrm{EI}_{\mathrm{it}}$ & $\begin{array}{l}-0.081 \\
(0.089)\end{array}$ & $\begin{array}{l}-0.001 \\
(0.019)\end{array}$ & $\begin{array}{l}0.017 * \\
(0.011)\end{array}$ & $\begin{array}{l}0.019 * \\
(0.011)\end{array}$ & $\begin{array}{l}0.001 \\
(0.012)\end{array}$ & $\begin{array}{l}0.004 \\
(0.013)\end{array}$ & $\begin{array}{l}-0.010 \\
(0.013)\end{array}$ \\
\hline $\mathrm{TD}_{\text {it }}$ & $\begin{array}{l}-1.84^{*} \\
(0.995)\end{array}$ & $\begin{array}{l}0.051 \\
(0.192)\end{array}$ & $\begin{array}{l}0.243^{* *} \\
(0.114)\end{array}$ & $\begin{array}{l}0.238^{* *} \\
(0.119)\end{array}$ & $\begin{array}{l}0.282^{* *} \\
(0.121)\end{array}$ & $\begin{array}{l}0.082 \\
(0.121)\end{array}$ & $\begin{array}{l}-0.075 \\
(0.180)\end{array}$ \\
\hline Constant $(\alpha)$ & $\begin{array}{l}275.174 \\
(613.909)\end{array}$ & $\begin{array}{l}-11.486 \\
(139.070)\end{array}$ & $\begin{array}{l}-156.641 * * \\
(72.687)\end{array}$ & $\begin{array}{l}-21.938 \\
(81.629)\end{array}$ & $\begin{array}{l}-3.005 \\
(77.829)\end{array}$ & $\begin{array}{l}-116.105^{*} \\
(71.580)\end{array}$ & $\begin{array}{l}-94.219 \\
(114.419)\end{array}$ \\
\hline Number of observations & 122 & 122 & 122 & 122 & 122 & 122 & 122 \\
\hline Adjusted R squared & 0.883 & 0.877 & 0.936 & 0.863 & 0.752 & 0.843 & 0.910 \\
\hline Fixed effects p-value (across space and time) & 0.000 & 0.000 & 0.000 & 0.000 & 0.000 & 0.000 & 0.000 \\
\hline Hausman test & 0.000 & 0.041 & 0.000 & 0.014 & 0.000 & 0.000 & 0.004 \\
\hline $\mathrm{p}$-value for model significance & 0.000 & 0.000 & 0.000 & 0.000 & 0.000 & 0.000 & 0.000 \\
\hline
\end{tabular}

Source: Author's own computation based on data described in section 3.

Note: Hausman test compares between POLS and LSDV techniques. While the null hypothesis requires that both POLS and LSDV are consistent, the alternative hypothesis holds that POLS is not consistent while LSDV is consistent. The parentheses contain the standard errors. ${ }^{*} \mathrm{p}<.10 .{ }^{*} \mathrm{p}<.05 .{ }^{*} * \mathrm{p}<.01$.

Table 4 provides the results from the GMM-IV technique. As seen in the table, the coefficients of the lagged dependent variables are positive and largely significant, highlighting the persistence of inequality. Compared to LSDV, results from the GMM-IV estimator indicate that the impact of social benefits on the Gini coefficient remains negative but becomes more statistically significant at $1 \%$ level. Specifically, a given increase in social benefits results in a 0.280 reduction in the Gini coefficient (in line with the political economy-growth model of Alesina and Perotti, 1994). In terms of standard deviation changes, the result suggests that a 1.115 decrease in the Gini coefficient is expected with a one standard deviation increase in social benefits. Similarly, a one standard deviation increase in social benefits leads to 0.295 standard deviation decrease in the Gini coefficient. These results suggest that the EU-15 countries with higher social benefits may experience a less unequal income distribution. Upon employing the GMM-IV estimator in regressing different income groups on social benefits, this study finds that the impact of social benefits on the low income groups remains significantly positive though reduces in size. Similarly, its impact on the 90th percentile remains significantly negative but reduces marginally. Also, the positive impact of social benefits on the 40th percentile becomes significant.

As seen in Table 4, the GMM-IV technique is confirmed to be consistent by the Arellano-Bond test for zero autocorrelation (Arellano \& Bond, 1991). Likewise, Sargan's test 
fails to reject the null hypothesis supporting the validity of the instruments (Sargan, 1958). Accordingly the GMM-IV estimator is selected as the preferred technique since it is a more general solution to endogeneity. Additionally, it robustly addresses inequality persistence and allows for comparison between the long and short run impacts of social benefits.

Table 4. Social benefits and income inequality: dynamic GMM-IV estimator.

\begin{tabular}{|c|c|c|c|c|c|c|c|}
\hline & Gini & (P10) & (P20) & (P40) & (P60) & (P80) & $(\mathbf{P 9 0 )}$ \\
\hline L. Inequality it & $\begin{array}{l}0.230 * * * \\
(0.078)\end{array}$ & $\begin{array}{l}0.220 * * \\
(0.106)\end{array}$ & $\begin{array}{l}0.326 * * * \\
(0.090)\end{array}$ & $\begin{array}{l}0.090 \\
(0.089)\end{array}$ & $\begin{array}{l}0.098 \\
(0.117)\end{array}$ & $\begin{array}{l}0.064 \\
(0.131)\end{array}$ & $\begin{array}{l}0.275 * * * \\
(0.079)\end{array}$ \\
\hline Benefits $_{\text {it }}$ & $\begin{array}{l}-0.280 \text { *** } \\
(0.110)\end{array}$ & $\begin{array}{l}0.061 * \\
(0.036)\end{array}$ & $\begin{array}{l}0.033^{*} \\
(0.019)\end{array}$ & $\begin{array}{l}0.025 \text { ** } \\
(0.012)\end{array}$ & $\begin{array}{l}0.004 \\
(0.015)\end{array}$ & $\begin{array}{c}-0.013 \\
(0.025)\end{array}$ & $\begin{array}{l}-0.025^{*} \\
(0.016)\end{array}$ \\
\hline TUD $_{\text {it }}$ & $\begin{array}{l}-0.054 \\
(0.082)\end{array}$ & $\begin{array}{l}0.000 \\
(0.025)\end{array}$ & $\begin{array}{l}0.017^{*} \\
(0.010)\end{array}$ & $\begin{array}{l}0.013 \\
(0.012)\end{array}$ & $\begin{array}{l}-0.002 \\
(0.015)\end{array}$ & $\begin{array}{l}-0.034^{*} \\
(0.018)\end{array}$ & $\begin{array}{l}-0.002 \\
(0.020)\end{array}$ \\
\hline $\mathrm{PT}_{\text {it }}$ & $\begin{array}{l}0.858 * * * \\
(0.261)\end{array}$ & $\begin{array}{l}-0.110 \\
(0.094)\end{array}$ & $\begin{array}{l}-0.076^{*} \\
(0.043)\end{array}$ & $\begin{array}{l}-0.115^{\text {**** }} \\
(0.047)\end{array}$ & $\begin{array}{l}-0.080^{*} \\
(0.052)\end{array}$ & $\begin{array}{l}-0.096 * * \\
(0.049)\end{array}$ & $\begin{array}{l}-0.095^{*} \\
(0.052)\end{array}$ \\
\hline $\mathrm{GDP}_{\text {it }}$ & $\begin{array}{l}104.413 \\
(162.126)\end{array}$ & $\begin{array}{l}9.054 \\
(55.741)\end{array}$ & $\begin{array}{l}-2.949 \\
(22.536)\end{array}$ & $\begin{array}{l}-7.034 \\
(23.881)\end{array}$ & $\begin{array}{l}-4.369 \\
(23.610)\end{array}$ & $\begin{array}{l}-28.227 \\
(32.572)\end{array}$ & $\begin{array}{l}-53.146 \\
(45.181)\end{array}$ \\
\hline $\mathrm{GDP}_{\mathrm{it}}^{2}$ & $\begin{array}{l}-4.424 \\
(7.592)\end{array}$ & $\begin{array}{l}-0.438 \\
(2.620)\end{array}$ & $\begin{array}{l}0.089 \\
(1.050)\end{array}$ & $\begin{array}{l}0.303 \\
(1.116)\end{array}$ & $\begin{array}{l}0.090 \\
(1.119)\end{array}$ & $\begin{array}{l}1.201 \\
(1.546)\end{array}$ & $\begin{array}{l}2.480 \\
(2.134)\end{array}$ \\
\hline Unemployment $_{i t}$ & $\begin{array}{l}0.217 * * * \\
(0.043)\end{array}$ & $\begin{array}{l}-0.053^{* * *} \\
(0.021)\end{array}$ & $\begin{array}{l}-0.020 * * * \\
(0.007)\end{array}$ & $\begin{array}{l}-0.012 \\
(0.009)\end{array}$ & $\begin{array}{l}-0.021 * * \\
(0.009)\end{array}$ & $\begin{array}{l}-0.007 \\
(0.014)\end{array}$ & $\begin{array}{l}0.004 \\
(0.0143)\end{array}$ \\
\hline Finance $_{i t}$ & $\begin{array}{l}-0.020 * * * \\
(0.006)\end{array}$ & $\begin{array}{c}0.002 * \\
(0.001)\end{array}$ & $\begin{array}{l}0.001 \\
(0.001)\end{array}$ & $\begin{array}{l}0.002 * * * \\
(0.000)\end{array}$ & $\begin{array}{l}0.002 * * \\
(0.000)\end{array}$ & $\begin{array}{l}0.002 * \\
(0.001)\end{array}$ & $\begin{array}{l}0.000 \\
(0.001)\end{array}$ \\
\hline $\mathrm{TO}_{\text {it }}$ & $\begin{array}{l}-0.034^{* * * *} \\
(0.012)\end{array}$ & $\begin{array}{c}0.002 \\
(0.003)\end{array}$ & $\begin{array}{l}0.002 \\
(0.002)\end{array}$ & $\begin{array}{l}0.003^{* *} \\
(0.001)\end{array}$ & $\begin{array}{l}0.004^{* * *} \\
(0.001)\end{array}$ & $\begin{array}{l}0.004^{* * *} \\
(0.002)\end{array}$ & $\begin{array}{l}0.003 \\
(0.003)\end{array}$ \\
\hline $\mathrm{EI}_{\mathrm{it}}$ & $\begin{array}{l}-0.123 * * * \\
(0.047)\end{array}$ & $\begin{array}{l}-0.000 \\
(0.015)\end{array}$ & $\begin{array}{l}0.023 * * * \\
(0.008)\end{array}$ & $\begin{array}{l}0.017 * * * \\
(0.005)\end{array}$ & $\begin{array}{l}0.007 \\
(0.005)\end{array}$ & $\begin{array}{l}0.000 \\
(0.011)\end{array}$ & $\begin{array}{l}-0.011 \\
(0.010)\end{array}$ \\
\hline $\mathrm{TD}_{\text {it }}$ & $\begin{array}{l}0.093 \\
(0.622)\end{array}$ & $\begin{array}{l}-0.346 \\
(0.271)\end{array}$ & $\begin{array}{l}0.014 \\
(0.127)\end{array}$ & $\begin{array}{l}0.057 \\
(0.079)\end{array}$ & $\begin{array}{l}0.207 \\
(0.129)\end{array}$ & $\begin{array}{l}0.197 \\
(0.233)\end{array}$ & $\begin{array}{l}0.226 \\
(0.207)\end{array}$ \\
\hline Constant $(\alpha)$ & $\begin{array}{l}-554.363 \\
(847.355)\end{array}$ & $\begin{array}{l}-44.253 \\
(290.669)\end{array}$ & $\begin{array}{l}20.826 \\
(118.276)\end{array}$ & $\begin{array}{c}43.617 \\
(125.463)\end{array}$ & $\begin{array}{l}41.714 \\
(121.309)\end{array}$ & $\begin{array}{l}171.939 \\
(168.018)\end{array}$ & $\begin{array}{l}290.777 \\
(234.267)\end{array}$ \\
\hline Number of observations & 82 & 82 & 82 & 82 & 82 & 82 & 82 \\
\hline AR(1) Test p-value & 0.020 & 0.018 & 0.031 & 0.027 & 0.072 & 0.034 & 0.022 \\
\hline AR(2) Test p-value & 0.808 & 0.738 & 0.774 & 0.467 & 0.963 & 0.390 & 0.958 \\
\hline Sargan Test p-value & 0.267 & 0.471 & 0.232 & 0.229 & 0.168 & 0.244 & 0.480 \\
\hline $\mathrm{p}$-value for model significance & 0.000 & 0.000 & 0.000 & 0.000 & 0.000 & 0.000 & 0.000 \\
\hline
\end{tabular}

Source: Author's own computation based on data described in section 3.

Note: The parentheses contain the standard errors. AR(1): Arellano-Bond test for zero first order autocorrelation. $\operatorname{AR}(2)$ : Arellano-Bond test for zero second order autocorrelation. ${ }^{*} \mathrm{p}<.10 .{ }^{*} \mathrm{p}<.05 . * * * \mathrm{p}<.01$.

\subsubsection{Results for the Control Variables}

Although social benefits represent the primary interest variable of this study, some of the results obtained from the GMM-IV technique for the control variables are quite interesting. The results provide support (though a weak one) for Kuznets inverted-U hypothesis (Kuznets, 1955). As seen in Table 4, the Gini coefficient has a positive relationship with per capita GDP but a negative relationship with the square of per capita GDP. A one percent increase in per capita GDP results in a 1.044 increase in the Gini coefficient. Also, a one percent increase in the square of per capita GDP results in a 0.442 decrease in the Gini coefficient.

The results also show that high unemployment rate has a significantly positive impact on the Gini coefficient and a negative impact on the low income groups. A given increase in the unemployment rate results in a 0.217 increase in the Gini coefficient. In terms of standard deviation changes, the result suggests that a 0.922 increase in the Gini coefficient is expected with one standard deviation increase in the unemployment rate. This result supports the popular hypothesis that unemployment increases inequality due to the fact that high unemployment rates are usually associated with economic downturns and during such periods, 
low-skilled workers on the bottom rung of the income distribution are usually the first group of workers to be dismissed when firms downsize. Eventually, this results in a fall in their earnings and ultimately increases inequality (Blank \& Card, 1993).

Likewise, trade openness has a significantly negative impact on the Gini coefficient as well as a significantly positive impact on the middle income groups. A given increase in trade openness results in a 0.034 decrease in the Gini coefficient. In terms of standard deviation changes, a 2.251 decrease in the Gini coefficient is expected with a one standard deviation increase in trade openness. This provides some support for the arguments based on the Heckscher-Ohlin (HO) theory (Heckscher, 1919; Ohlin, 1933) which suggests that as a country becomes more open to trade, the income share held by the abundant factors increases and if other than the high income groups are the beneficiaries of trade openness, inequality would likely reduce (Anderson, 2005).

Also, an increase in finance has a negative impact on the Gini coefficient and a positive impact on the middle income groups. A given increase in finance results in a 0.020 decrease in the Gini coefficient. In terms of standard deviation changes, the result suggests that a 1.115 decrease in the Gini coefficient is expected with a one standard deviation increase in finance. This result supports the theories predicting that an increase in finance would reduce inequality by providing less privileged individuals with better access to financial services (Becker \& Tomes, 1979).

Similarly, the results show that economic integration has a significantly negative impact on the Gini coefficient and a significantly positive impact on the 20th and 40th percentiles. A given increase in economic integration results in a 0.123 decrease in the Gini coefficient. In terms of standard deviation changes, the result suggests that a 1.206 decrease in the Gini coefficient is expected with a one standard deviation increase in economic integration. This result supports arguments based on the factor price equalization theorem of Samuelson (1953); which suggests that an increase in economic integration ensures convergence and ultimately reduces inequality (Ghosh \& Faber, 2010).

Additionally, this study finds support (though a weak one) for Solow's skill-biased technological change model which suggests that technological advancement can widen the wage gap between skilled and unskilled workers (Solow, 1957). The results reveal that technological development has a positive impact on the Gini coefficient and a negative impact on the 10th percentile. A given increase in technological development results in a 0.093 increase in the Gini coefficient. In terms of standard deviation changes, the result suggests that a 0.075 increase in the Gini coefficient is expected with a one standard deviation increase in technological development.

Further, trade union density has a negative impact on the Gini coefficient and a significantly positive impact on the 20th percentile. A given increase in trade union density results in a 0.054 decrease in the Gini coefficient. In terms of standard deviation changes, the result suggests that a 1.159 decrease in the Gini coefficient is expected with a one standard deviation increase in trade union density. This provides some support for the theories of Lotka (1925) and Volterra (1931) which suggest that trade union density has a negative 
impact on inequality.

Further, the results suggest that an increase in progressive taxes has a positive impact on the Gini coefficient and a negative impact on almost all income groups. A given increase in progressive taxes results in a 0.858 increase in the Gini coefficient. In terms of standard deviation changes, the result suggests that a 0.906 increase in the Gini coefficient is expected with a one standard deviation increase in progressive taxes. Hence, the result does not provide support for the Jakobsson-Fellman theorem which suggests that the gap between the rich and the poor can only be reduced through an increase in progressive taxes (Jakobsson, 1976; Fellman, 1976). Although this result runs contrary to this study's expectation, the hypotheses of Allingham (1979) and Ebert and Moyes (2003) make some attempts in clarifying that progressive taxes can increase inequality if they are designed in a manner such that the elasticity of gross income is very high relative to the non-taxed income.

\subsubsection{Social Benefits and Inequality in the Long Run}

The GMM-IV estimator is employed in examining the long run relationship between social benefits and inequality. In the long run, the sizes of all the parameter estimates become noticeably larger. Hence, in the long run, there would be an increase in the negative impact of social benefits on the Gini coefficient, its positive impact on the low income groups and its negative impact on the 90th percentile. In the long run, a given increase in social benefits results in a 0.364 decrease in the Gini coefficient. In terms of standard deviation changes, the result suggests that a 1.449 decrease in the Gini coefficient is expected with a one standard deviation increase in social benefits. Similarly, a one standard deviation increase in social benefits leads to 0.383 standard deviation decrease in the Gini coefficient. Nonetheless, the signs and significance of the long run parameters remain largely unchanged.

\subsubsection{Comparing Results and Hypotheses}

Based on the results from this study's preferred GMM-IV technique, there exists some support for this study's hypothesis since social benefits have a significant impact on inequality at an aggregate level as well as on the income shares of different income groups. The result regarding the impact of social benefits across the income groups further lends credence to the political economy-growth model of Alesina and Perotti (1994) which suggests that redistributive policies would reduce the incomes of the high income groups in a manner that benefits other income groups without contributing to inequality. Additionally, the results are similar to the findings of the European commission (2017), Raitano (2016) and Heady (2001).

However, no concrete support is found for the median voter model of Meltzer and Richard (1981) which suggests that the median voters' pursuit of their personal interests would result in a more unequal income distribution. Further, no support is found for hypotheses based on the mainstream labour supply theory (Aaberge \& Colombino, 2006); which suggest that benefits could serve as an incentive for recipients to reduce their working hours, thereby increasing wage inequality. 


\subsection{Sensitivity Analysis}

In this section, this study evaluates the reliability of its preferred GMM-IV technique by conducting some robustness checks.

Firstly, the income groups are represented with a different set of income percentiles. The low, middle and high income groups are represented with 25 th percentile, 50th percentile and 75 th percentiles respectively. In all cases, the results further corroborate previous findings. Secondly, this study controls for possible outliers among the countries under investigation. Overtime, the level of inequality in countries such as Finland, Belgium, Sweden and Denmark has remained relatively low (OECD, 2011). As noted by Development Finance International and Oxfam (2017), these countries invest a lot of efforts on social expenditures. Accordingly, it is necessary to account for the potential impact of these countries on the results obtained. To this effect, the GMM-IV estimation is repeated by methodically excluding these countries one after another. Again, the results confirm previous findings indicating that the results are not biased by extreme values. Thirdly, a sample sensitivity check is conducted across time by accounting for the global financial crisis years. The hypotheses proposed by Attanasio and Weber, (2010) and Calvo, (2013) suggest that financial crisis impact significantly on inequality. Accordingly, the robustness of the GMM-IV results is tested by including dummy variables that account for the level effect of the 2007-2009 crisis. On average, the Gini coefficient is 0.068 higher during the crisis. Nonetheless, the results are generally similar to previous findings. As such, the results are not driven by the anomalies associated with the crisis years. Fourthly, employment protection legislation is included as an additional control variable. This variable is included on the basis of the labour market regulation hypotheses proposed by Burniaux et al., (2006) and Checci and Garcia-Penalosa, (2005). However, the variable is generally observed to have an unclear influence on inequality as well as the income groups. Likewise, the coefficient of social benefits remains largely unchanged. Fifthly, the square of social benefits is included as an additional control variable on the basis of Bénabou's (2000) stochastic growth model which suggests inequality increases at low levels of social benefits and decreases as social benefits become considerably high. The results show that the square of social benefits in fact has a positive and insignificant impact on inequality. Hence, no support is found for Bénabou's (op. cit.) stochastic growth model. Likewise, the coefficient of social benefits remains similar to previous findings.

\section{Conclusion}

Income inequality in Europe has been an issue of crucial importance since the 1980s during which the income distribution became precariously unequal largely owing to policies that were pro-liberalization, pro-welfare state retrenchment and pro-financialization (OECD, 2011). Concerns regarding inequality were further heightened by the possible implications of the dramatic reduction in many European countries' fiscal stimulus programmes following the 2007-2009 financial crisis years.

Meanwhile, there exists a debate in the theoretical literature regarding the impact of social benefits on inequality. The median voter model of Meltzer and Richard (1981) suggest that a 
rise in social benefits would likely raise the inequality level due to the median voters' pursuit of their personal interests. However, the political economy-growth model of Alesina and Perotti (1994) predicts that an increase in social benefits would achieve the objective of reducing inequality as redistributive policies would reduce the incomes of the high income groups in a manner that benefits other income groups without contributing to inequality. Additionally, Bénabou's (2000) stochastic growth model suggests that inequality increases at low levels of social benefits and decreases as social benefits become considerably high. Further, the hypotheses based on the mainstream labour supply theory (Aaberge \& Colombino, 2006) suggest that benefits could serve as an incentive for recipients to reduce their working hours, thereby increasing wage inequality.

In contributing to this debate, this study considers the EU-15 countries for the period 1995-2015. Inequality is measured using the Gini coefficient data from Eurostat's Database. This study advances the literature by evaluating the impact of social benefits on the low, middle and high income groups. The income shares of six different income percentiles are used in representing the income groups. The estimation techniques employed are: Pooled Ordinary Least Squares (POLS), Least Squares Dummy Variables (LSDV) and dynamic GMM-IV estimator of Arellano and Bond (1991). The use of multiple techniques makes this research more robust in addressing issues related to inequality persistence, endogeneity, heterogeneity, stationarity, autocorrelation and heteroscedasticity. This research also contributes to knowledge by considering vital determinants of inequality which many studies ignore. These include: finance and trade union density.

Due to the fact that diagnostic tests indicate that the results from the GMM-IV estimator are consistent and the associated instrumental variables are valid, this estimator is selected as the preferred technique. Results from this technique reveal that social benefits have a significantly negative effect on inequality, a positive impact on the low and middle income groups and a negative impact on the high income groups. Generally, the results from this study support the political economy-growth model of Alesina and Perotti (1994). However, no support is found for: the median voter model of Meltzer and Richard (1981), Bénabou's (2000) stochastic growth model and the hypotheses based on the mainstream labour supply theory (Aaberge \& Colombino, 2006).

Based on its findings, this study recommends firstly; that policymakers intensify efforts in raising social benefits; a reduction in social benefits is likely to adversely affect the low income groups and consequently widen the gap between the rich and the poor. Secondly, this study recommends that the welfare system be organized in a manner in which social benefits are not hijacked by the non-poor but instead increase the income shares of the low income groups. Social benefits may become counterproductive when they do not serve the interest of the individuals in the bottom rung of the distribution.

At this point, it is necessary to observe that this study experienced data limitations with regards to the Gini coefficient and the income percentiles for Sweden and Denmark. Nonetheless, in the sensitivity analysis section, estimations are repeated by excluding several countries (including Sweden and Denmark) one after another. The results largely remain 
similar to previous findings indicating that the results are robust and not driven by the values of any country. Further, data constraints limit the scope of this study to the EU-15 countries over the period 1995-2015. Nonetheless, this provides this study with observations that are moderately large enough to conduct a robust analysis.

Notwithstanding the above limitations, this study substantially achieves its objective of investigating the impact of social benefits on the aggregate level of inequality as well as on the income shares of different income groups in the EU-15 countries over the period 1995-2015. Future studies may however extend this research to the EU-28 countries and cover a longer time span when the relevant data become available. Additionally, the respective impacts of the sovereign debt and financial crises on the fiscal policy tools may also be looked into.

\section{Acknowledgement}

I am very grateful to Dr. Peter Phelps for providing me with valuable comments and feedbacks during the course of this study.

\section{References}

Aaberge, R., \& Colombino, U. (2006). Designing optimal taxes with a microeconometric model of household labour supply. IZA Discussion Paper Number 2468, Institute for the Study of Labor (IZA).

Agnello, L., Fazio, G., \& Sousa, R. M. (2016). National fiscal consolidations and regional inequality in Europe. Cambridge Journal of Regions, Economy and Society, 9(1), 59-80. https://doi.org/10.1093/cjres/rsv033

Alesina, A., \& Perotti, R. (1994). The political economy of growth: A critical survey of the recent literature. World Bank Economic Review, 8, 351-371. https://doi.org/10.1093/wber/8.3.351

Alesina, A., \& Rodrik, D. (1994). Distributive politics and economic growth. Quarterly Journal of Economics, 109, 465-490. https://doi.org/10.2307/2118470

Allingham, M. (1979). Inequality and progressive taxation: an example. Journal of Public Economics, 11, 273-274. https://doi.org/10.1016/0047-2727(79)90009-4

Almon, S. (1965). The distributed lag between capital appropriations and expenditures. Econometrica, 33, 178-196. https://doi.org/10.2307/1911894

Anderson, E. (2005). Openness and inequality in developing countries: a review of theory and recent evidence. World Development, 33(7), 1045-1063. https://doi.org/10.1016/j.worlddev.2005.04.003

Arellano, M., \& Bond, S. (1991). Some tests of specification for panel data: monte Carlo evidence and an application to employment equations. Review of Economic Studies, 58(2), 277-297. https://doi.org/10.2307/2297968

Arestis, P., \& Gonzalez-Martinez, A. R. (2016). Income inequality: implications and relevant 
economic policies. Panoeconomicus, 63(1), 1-24. https://doi.org/10.2298/PAN1601001A

Arestis, P., \& Phelps, P. (2018). Inequality implications of EMU membership: a reassessment. Environment and Planning A.

Atkinson, A. B. (2013). Reducing income inequality in Europe. Journal of European Labor Studies, 2(1), 1-11. https://doi.org/10.1186/2193-9012-2-12

Attanasio, O., \& Weber, G. (2010). Consumption and saving: models of intertemporal allocation and their implications for public policy. Journal of Economic Literature, 48(3), 693-751. https://doi.org/10.1257/jel.48.3.693

Ball, L., Furceri, D., Leigh, D., \& Loungani, P. (2013). The distributional effects of fiscal consolidation. IMF Working Paper Number 13/151, International Monetary Fund, Washington, D.C. https://doi.org/10.5089/9781475551945.001

Bargain, O., Jara, H. X., \& Rodriguez, D. (2017). Learning from your neighbour: tax-benefit systems swaps in Latin America. The Journal of Economic Inequality, 15(4), 369-392. https://doi.org/10.1007/s10888-017-9367-5

Barr, N. (2004). The economics of the welfare state. London: Oxford University Press.

Barro, R. J. (1999). Inequality, growth, and investment. NBER Working Paper Number 7038, National Bureau of Economic Research, Cambridge, MA. https://doi.org/10.3386/w7038

Barro, R. J. (2000). Inequality and growth in a panel of countries. Journal of Economic Growth, 5, 5-32. https://doi.org/10.1023/A:1009850119329

Becker, G. S., \& Tomes, N. (1979). An equilibrium theory of the distribution of income and intergenerational mobility. Journal of Political Economy, 87(6), 1153-1189. https://doi.org/10.1086/260831

Beetsma, R., Giuliodori, M., \& Hanson, J. (2012). Budgetary consolidation under different exchange rate regimes. Economics Letters, 117(3), 912-916. https://doi.org/10.1016/j.econlet.2012.07.010

Bénabou, R. (2000). Unequal societies: Income distribution and the social contract. American Economic Review, 90, 96-129. https://doi.org/10.1257/aer.90.1.96

Bergh, A. (2005). On the counterfactual problem of welfare state research: how can we measure redistribution? European Sociological Review, 21(4), 345-357. https://doi.org/10.1093/esr/jci024

Bertola, G. (2010). Inequality, integration, and policy: issues and evidence from EMU. The Journal of Economic Inequality, 8, 345-365. https://doi.org/10.1007/s10888-009-9126-3

Blank, R. M., \& Card, D. (1993). Poverty, income distribution and growth: are they still connected? Brookings Papers on Economic Activity, 2, 285-325. https://doi.org/10.2307/2534568

Burniaux, J. M., Padrini, F., \& Brandt, N. (2006). Labour market performance, income 
inequality and poverty in OECD countries. OECD Economics Department Working Paper Number 500, Organisation for Economic Co-operation and Development, Paris, France.

Butler, S., \& Kondratas, A. (1987). Out of the poverty trap: a conservative strategy for welfare reform. New York: The Free Press.

Calvo, G. (2013). Puzzling over the anatomy of crises: liquidity and the veil of finance. IMES Discussion Paper Series 2013-E-9, Institute for Monetary and Economic Studies, Japan.

Checchi, D., \& Garcia-Penalosa, C. (2005). Labour market institutions and the personal distribution of income in the OECD. IZA Discussion Paper Number 1681, Institute for the Study of Labor (IZA).

Chen, S. (2010). The developing world is poorer than we thought, but no less successful in the fight against poverty. Quarterly Journal of Economics, 125(4), 1577-1625. https://doi.org/10.1162/qjec.2010.125.4.1577

Cingano, F. (2014). Trends in income inequality and its impact on economic growth. OECD Social, Employment and Migration Working Paper No. 163, Organisation for Economic Co-operation and Development, Paris, France.

Dafermos, J., \& Papatheodorou, C. (2012). Economic crisis and poverty in Greece and EU: the effects of macroeconomics and social protection. Bank of Greece Report, Athens, Greece.

Development Finance International and Oxfam. (2017). The Commitment to Reducing Inequality Index. Retrieved July 20, 2018, from https://www.oxfam.org/sites/www.oxfam.org/

Dutt, A. K. (2015). Growth and distribution in heterodox models with managers and financiers. Metroeconomica, 67(2), 364-396. https://doi.org/10.1111/meca.12102

Easterly, W. (2000). The middle-class consensus and economic development. The World Bank Development Research Group Working Paper No. 2346. https://doi.org/10.1596/1813-9450-2346

Ebert, U., \& Moyes, P. (2003). The difficulty of income redistribution with labour supply. Economics Bulletin, 8, 1-9.

Eurofound. (2010). Why socio-economic inequalities increase? Facts and policy responses in Europe. Publications Office of the European Union, Luxembourg.

Eurofound. (2017). European semester thematic factsheet addressing inequalities. Publications Office of the European Union, Luxembourg.

Eurostat. (2018). Intra and extra-EU trade. Retrieved July 7, 2018, from https://data.europa.eu/euodp/en/data/dataset/FXQMUw9I5qJ3eqHLwdeoA

Fellman, J. (1976). The effect of transformations of Lorenz curves. Econometrica, 44, 823-824. https://doi.org/10.2307/1913450

Foster, J., Seth, S., Lokshin, M., \& Sajaia, Z. (2013). A unified approach to measuring poverty and inequality: theory and practice. Washington, DC: World Bank Publications. 
https://doi.org/10.1596/978-0-8213-8461-9

Fuest, C., Niehues, J., \& Peichl, A. (2010). The redistributive effects of tax benefit systems in the enlarged EU. Public Finance Review, 38(4), 473-500. https://doi.org/10.1177/1091142110373480

Ghosh, S., \& Faber, G. (2010). Economic integration in Europe and income divergence over EU regions (1995-2006). Utrecht School of Economics Discussion Paper Series Number 10-19, Tjalling C. Koopmans Research Institute, Netherlands. https://doi.org/10.2139/ssrn.1840558

Gordon, D. M., Richard, E., \& Michael, R. (1982). Segmented work, divided workers. Cambridge: Cambridge University Press.

Greenwood, J., \& Jovanovic, B. (1990). Financial development, growth, and the distribution of income. Journal of Political Economy, 98(5), 1076-1107. https://doi.org/10.1086/261720

Griliches, Z. (1967). Distributed lags: a survey. Econometrica, 35, 16-49. https://doi.org/10.2307/1909382

Gustafsson, B., \& Johansson, M. (1997). In search for a smoking gun: what makes income inequality vary over time in different countries? LIS Working Paper Number 172, Luxembourg Income Study, Luxembourg.

Haughton, J., \& Khandker, S. (2009). Handbook of poverty and inequality. Washington, DC: World Bank Publications.

Hausman, J. (1978). Specification tests in econometrics. Econometrica, 46, 1251-1271. https://doi.org/10.2307/1913827

Hayes, T. J., \& Vidal, D. X. M. (2015). Fiscal policy and economic inequality in the US states: Taxing and spending from 1976 to 2006. Political Research Quarterly, 68, 392-407. https://doi.org/10.1177/1065912915578461

Heady, C., Mitrakos, T., \& Tsakloglou, P. (2001). The distributional impact of social transfers in the European Union: evidence from the ECHP. IZA Discussion Paper Number 356, Institute for the Study of Labor (IZA).

Heckscher, E. (1919). The effect of foreign trade on the distribution of income. Ekonomisk Tidskrift, 21, 497-512. https://doi.org/10.2307/3437610

Hsiao, C., Appelbe, T. W., \& Dineen, C. R. (1993). A general framework for panel data analysis with an application to Canadian customer dialed long distance service. Journal of Econometrics, 59, 63-86. https://doi.org/10.1016/0304-4076(93)90039-8

Hsiao, C., Mountain, D. C., \& Ho-Illman, K. (1995). Bayesian integration of end-use metering and conditional demand analysis. Journal of Business and Economic Statistics, 13, 315-326. https://doi.org/10.1080/07350015.1995.10524605

IMF. (2013). Income inequality and fiscal policy. IMF Working Paper Number SDN/12/08, 
International Monetary Fund, Washington, D.C.

Immervoll, H., Klas, L., Esko, M., Marja, R., \& Heikki, V. (2005). Static data “ageing” techniques. Accounting for population changes in tax-benefit microsimulation models, Euromod Working Paper Number EM7/05, Institute for Social and Economic Research, University of Essex.

International Labour Organization. (1982). Resolution concerning statistics of the economically active population, employment, unemployment and underemployment. ILO Report, International Labour Organization, Geneva, Switzerland.

Iosifidi, M., \& Mylonidis, N. (2016). Relative effective taxation and income inequality: Evidence from OECD countries. Journal of European Social Policy, 27, 57-76. https://doi.org/10.1177/0958928716672182

Ivanova, M. (2007). Inequality and government policies in Central and Eastern Europe. East European Quarterly, 41, 167-204.

Jakobsson, U. (1976). On the measurement of the degree of progression. Journal of Public Economics, 5, 161-168. https://doi.org/10.1016/0047-2727(76)90066-9

Kenworthy, L. (1999). Do social-welfare policies reduce poverty? A cross-national assessment. Social Forces, 77(3), 1119-1139. https://doi.org/10.2307/3005973

Kenworthy, L., \& Pontusson, J. (2005). Rising inequality and the politics of redistribution in affluent countries. Perspectives on Politics, 3(3), 449-471. https://doi.org/10.1017/S1537592705050292

Klevmarken, N. A. (1997). Behavioural modelling in micro simulation models: A survey. Uppsala University, Department of Economics Working Paper Number 1997:31, Uppsala, Sweden.

Koyck, L. M. (1954). Distributed lags and investment analysis. Amsterdam: North-Holland Publishing Company.

Kuznets, S. (1955). Economic growth and income inequality. American Economic Review, $45(1), 1-28$.

Lee, D. R. (1987). The tradeoff between equality and efficiency: short-run politics and long-run realities. Public Choice, 53, 149-165. https://doi.org/10.1007/BF00125846

Leshcke, J., \& Jepsen, M. (2012). Introduction: Crisis, policy responses and widening inequalities in the EU. International Labour Review, 151(4), 289-312. https://doi.org/10.1111/j.1564-913X.2012.00150.x

Lotka, A. J. (1925). Elements of physical biology. New York: Williams and Wilkins.

Madsen, J. B., Islam, M. R., \& Doucouliagos, H. (2018). Inequality, financial development and economic growth in the OECD, 1870-2011. European Economic Review, 101, 605-624. https://doi.org/10.1016/j.euroecorev.2017.11.004 


\section{Macrothink}

International Journal of Social Science Research

ISSN 2327-5510

2020, Vol. 8, No. 2

Meltzer, A. H., \& Richard, S. F. (1981). A rational theory of the size of government. Journal of Political Economy, 89, 914-927. https://doi.org/10.1086/261013

Meyer, B. (2002). Unemployment and workers' compensation programmes: rationale, design, labour supply and income support. Fiscal Studies, 23(1), 1-49. https://doi.org/10.1111/j.1475-5890.2002.tb00053.x

Milanovic, B. (2012). Global inequality recalculated and updated: the effect of new PPP estimates on global inequality and 2005 estimates. The Journal of Economic Inequality, 10(1), 1-18. https://doi.org/10.1007/s10888-010-9155-y

Murray, C. (1984). Losing ground: American social policy 1950-1980. New York: Basic Books.

Newey, W. K., \& West, K. D. (1987). A simple, positive-definite, heteroskedasticity and autocorrelation consistent covariance matrix. Econometrica, 55, 703-708. https://doi.org/10.2307/1913610

Niehues, J. (2010). Social spending generosity and income inequality: a dynamic panel approach. The Institute for the Study of Labor (IZA) Working paper No. 5178. https://doi.org/10.2139/ssrn.1724733

Obadić, A., Šimurina, N., \& Sonora, R. (2014). The effects of tax policy and labour market institutions on income inequality. Journal of Economics and Business, 32(1), 121-140.

OECD. (2011). An overview of growing income inequalities in OECD countries: main findings. OECD Report, Organisation for Economic Co-operation and Development, Paris, France.

OECD. (2016). OECD Employment and labour market statistics database: Trade Unions: Trade union Density. https://doi.org/10.1787/fbf99961-en

OECD. (2017). Understanding the socio-economic divide in Europe. OECD Report, Organisation for Economic Co-operation and Development, Paris, France.

OECD. (2018a). Income inequality indicator. https://doi.org/10.1787/459aa7f1-en

OECD. (2018b). Social spending indicator. https://doi.org/10.1787/7497563b-en

OECD. (2018c). Tax revenue. https://doi.org/10.1787/d98b8cf5-en

Ohlin, B. (1933). Interregional and international trade. Cambridge: Harvard University Press.

Ostry, M. J. D., Berg, M. A., \& Tsangarides, M. C. G. (2014). Redistribution, inequality, and growth. IMF Working Paper Number SDN/14/02, International Monetary Fund, Washington, D.C. https://doi.org/10.5089/9781484352076.006

Pacek, A., \& Freeman, B. (2017). The welfare state and quality of life: a cross-national analysis. Texas A\&M University Working Paper, Texas A\&M University Press. 
Pakes, A., \& Griliches, Z. (1984). Estimating distributed lags in short panels with an application to the specification of depreciation patterns and capital stock constructs. Review of Economic Studies, 51, 243-262. https://doi.org/10.2307/2297690

Parker, S. C. (1999). Income inequality and the business cycle: a survey of the evidence and some new results. Journal of Post Keynesian Economics, 21(2), 201-225. https://doi.org/10.1080/01603477.1998.11490191

Perotti, R. (1996). Growth, income distribution, and democracy: what the data say? Journal of Economic Growth, 1, 149-187. https://doi.org/10.1007/BF00138861

Phillips, P. C. B., \& Perron, P. (1988). Testing for a unit root in time series regression. Biometrika, 75, 335-346. https://doi.org/10.1093/biomet/75.2.335

Raitano, M. (2016). Income inequality in Europe since the crisis. Intereconomics, 51(2), 67-72. https://doi.org/10.1007/s10272-016-0579-x

Rodriguez, F. C. (1999). Inequality, redistribution, and rent-seeking. University of Maryland Department of Economics Working Paper, University of Maryland, College Park.

Rodríguez-Pose, A., \& Fratesi, U. (2004). Between development and social policies: the impact of European structural funds in objective 1 regions. Regional Studies, 38, 97-113. https://doi.org/10.1080/00343400310001632226

Salotti, S., \& Trecroci, C. (2015). Can fiscal policy mitigate income inequality and poverty? Retrieved August 6, 2018, from https://papers.ssrn.com

Samuelson, P. A. (1953). Prices of factors and goods in general equilibrium. Review of Economic Studies, 21, 1-20. https://doi.org/10.2307/2296256

Sargan, J. (1958). The estimation of economic relationships using instrumental variables. Econometrica, 26(3), 393-415. https://doi.org/10.2307/1907619

Solow, R. M. (1957). Technical change and the aggregate production function. The Review of Economics and Statistics, 39(3), 312-320. https://doi.org/10.2307/1926047

Volterra, V. (1931). Variations and fluctuations of the number of individuals in animal species living together. Animal Ecology, 409-448.

Whiteford, P. (2008). Redistribution in OECD welfare states. OECD Social. Employment and Migration Working Papers, Organisation for Economic Co-operation and Development, Paris, France.

World Bank. (2018a). Skills and Europe's labor market: how technological change and other drivers of skill demand and supply are shaping Europe's labor market. World Bank Report on The European Union, World Bank, Washington, DC.

World Bank, World Development Indicators. (2016). Trade as a percentage of Gross Domestic Product. Retrieved July 12, 2018, from https://data.worldbank.org/indicator/NE.TRD.GNFS.ZS 


\section{Macrothink}

International Journal of Social Science Research

ISSN 2327-5510 2020, Vol. 8, No. 2

World Bank, World Development Indicators. (2018b). Market capitalization of listed domestic companies as a percentage of GDP. Retrieved July 7, 2018, from https://data.worldbank.org/indicator/CM.MKT.LCAP.GD.ZS

\section{Copyrights}

Copyright for this article is retained by the author(s), with first publication rights granted to the journal.

This is an open-access article distributed under the terms and conditions of the Creative Commons Attribution license (http://creativecommons.org/licenses/by/4.0/). 